\title{
Relationship between sustainable development initiatives and improved company financial performance: A South African perspective
}

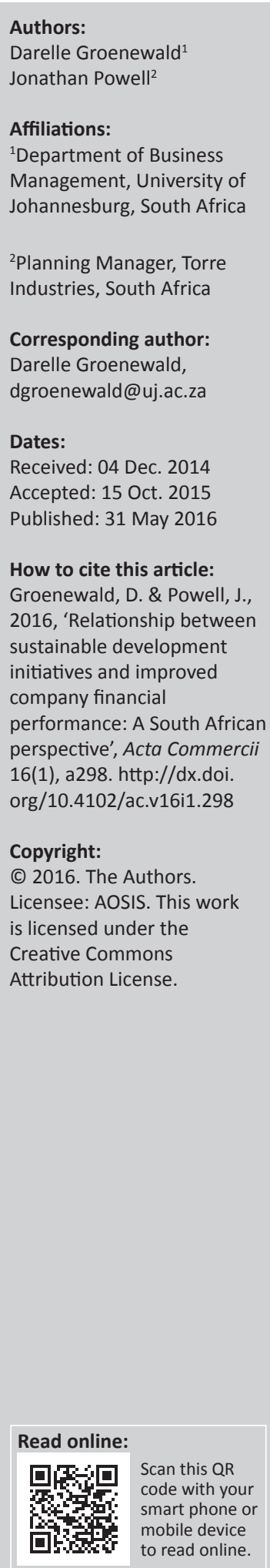

Orientation: Companies are under ever-increasing pressure from both internal and external stakeholders to consider the environmental and social impacts of their operations and to mitigate these impacts. This necessitates an investigation into the effect of sustainability initiatives on the financial performance (FP) of a company.

Research purpose: The study analysed the relationship between sustainability performance and FP in South African listed companies.

Motivation for the study: Some South African listed companies acknowledge in their sustainability reports that there is a link between sustainability development and long-term shareholder value. This implies that FP is linked to sustainable development performance. This relationship has not been researched for South African listed companies and therefore needs to be investigated.

Research design, approach and method: A similar research method was used as for an international study. Forty-five listed South African companies were selected as the sample. Their sustainable development reports were used for analysis. Data were analysed with the use of content and a canonical correlation analysis.

Main findings: The results of the study revealed that an overall positive relationship exists between sustainability performance and FP.

Practical implications: South African companies that have a high involvement and focus on specific sustainable development initiatives that are integrated into overall sustainable development strategy can deliver improved FP for the organisation and deliver long-term value to its shareholders.

Contribution: Six sustainable development aspects were found to be significantly correlated with improved FP and if incorporated into a company's sustainable development strategy can lead to increased successes.

\section{Introduction}

The concept of sustainable development has evolved over time but it is not since 1987, after the release of the Bruntland Commissions report (1987) on sustainable development, that companies have really started embedding the concept into how they operate, strategise and communicate within their markets. The financial crisis of 2008 has led to a shift in how companies operate. One of these shifts has been to focus not only on profit, but more consideration has been given to the environment and society. Dimitrov and Davey (2011:86) state that despite the benefits that companies accrue from business transactions, such as technological and economic progress, companies are faced with increasing criticism for creating social and environmental problems. These three aspects are also referred to as the triple-bottom line - triple-bottom line represents social, economic and environmental concerns. Sometimes, triple-bottom line is also known as the three ' $\mathrm{P}^{\prime} \mathrm{s}$ ': people, planet and profit. Companies can no longer only focus on achieving financial gains without taking into consideration the effects this has on the environment and the people (Brundtland 1987).

Companies realise that the ruthless depletion of natural resources and the exploitation of communities in which they operate and through which they generate their revenues will result in negative sentiment with their shareholders that may even lead to their demise (Esty \& Winston 2009:33). To mitigate these impacts, companies implement sustainability initiatives and communicate these initiatives through sustainability reporting (SR) (Searcy \& Elkhawas 2012:79). 
Companies are motivated to tract social development initiatives for the following seven reasons: (1) an enhanced ability to track progress against set targets and objectives, (2) developing greater awareness of broad environmental issues, (3) ensuring that through compliance and governance a company's license to operate is maintained, (4) their reputation is enhanced, (5) cost efficiencies are identified, (6) staff morale is improved and (7) all-round credibility from greater transparency is enhanced (Searcy \& Elkhawas 2012:80). Dimitrov and Davey (2011:86) state that the full consequences of conducting business have not been reflected in the financial statements as companies have been able to measure their profit success by excluding the bulk of transactional costs from social and environmental aspects. The limitations of the existing financial reporting frameworks for reporting environmental and social transactions are poorly understood, inadequately identified and not reported within a consistent framework, if reported at all, according to Dimitrov and Davey (2011:86).

The concept of sustainable development and sustainability may sometimes be misunderstood and ill-defined. This misunderstanding and confusion may be because of the numerous definitions of sustainability that can be found (Sutton 2004:1). The most commonly accepted meaning of sustainable development is the one proposed by the 1987 Brundtlund Report: 'Humanity has the ability to make development sustainable - to ensure that it meets needs of the present without compromising the ability of future generations to meet their own needs' (Brundtlund 1987:8).

Since the implementation of the King Commission's Code for Corporate Governance, SR has become mandatory in financial reports in South Africa. The financial performance (FP) and financial position of the company for any given financial year are measured by analysing the company's financial statements and these statements are prepared in accordance with International Financial Reporting Standards. The inclusion of sustainability in a company's financial reports indicates why it is important for companies to not only report on their finances but also on the effect of their business on the environment and the society. In 2011, the third revision of the 'King Code on Corporate Governance' stipulated that SR must be viewed as an integral part of a company's financial statements (Walker \& Meiring 2010). A company is required to report its intentions to improve the livelihood of communities and to reduce the negative effects that its operations my cause (PriceWaterhouse Coopers 2009:8). The King III code focuses on the importance of a company to disclose in its annual financial reports, both positive and negative effects that its operations may have on its stakeholders and environments in which it resides.

Taking into consideration companies' sustainability goals to not only create economic value and provide goods and services that enhance the standard of living but also engage actively in mitigating the different environmental and social problems they cause through their activities, the research study was based on an international research project conducted to determine if companies that proactively manage sustainability initiatives will deliver improved FP.

The article aims to discuss the relationship between proactive sustainable development initiatives and improved company FP of South African listed companies.

Although the concept of sustainable development has received extensive attention in South Africa, the relationship between sustainability performance and FP is excessively underexplored.

\section{Why sustainable development?}

According to the Sustainability Report, 2011, sustainable development highlights the importance of making decisions that recognise the connections between actions and effects on the environment, the economy and society; it is also about long-term thinking with respect to the kind of legacy that will be left to future generations. The Brundtland Report (1987) also acknowledges that short-term goals cannot be neglected in favour of preservation and protection; therefore, it did not advocate a halt in economic activity but stated that economic development cannot stop. The Brundtland Report (1987) advised that a course correction is required in order for economic development to fit within the planet's ecological and natural resource boundaries. The world's focus on the concept of sustainability development (SD) was to peak in 1992 when senior officials from 179 governments met at the UN Conference on Environment and Development, in Rio de Janeiro. The world's leaders had watched a series of potentially catastrophic events unfold across the globe including the leak of poisonous gas from a chemical plant at Bhopal, India; the Chernobyl disaster; the hole in the Antarctic ozone layer; leaking toxic chemical dumps; and growing fears regarding chemical contamination and conflicts over decreasing natural resources in the planet's forests and fisheries. The outcomes from these meetings included the finalisation of two international agreements, two statements of principles and a major action agenda on worldwide SD (Sustainability Report 2011). These events and agreements led to greater awareness across the globe of SD and responsible business practices; however, it was not until the King III Report on corporate governance that disclosure of risks to society and the environment became mandatory for the world's leading companies. This mandatory disclosure has now become commonly included in companies' SRs (Walker \& Meiring 2010:1).

\section{Sustainability reporting}

Sustainability Reporting (SR) has been defined as 'public reports by companies to provide internal and external stakeholders with a picture of the corporate position and activities on economic, environmental and social dimensions' (World Business Council for Sustainable Development 2002:8). The motivations for companies to track SD initiatives include an enhanced ability to track progress against set 
targets and objectives, to develop a greater awareness of broad environmental issues, ensuring that through compliance and governance a company's licence to operate is maintained, reputation enhancement, cost efficiencies identification, improved staff morale and, finally, improved all-round credibility from greater transparency (Searcy \& Elkhawas 2012:80).

There is no standard for SR and currently a number of different reports are used by companies to highlight the risks and benefits that business activities can have on the environments in which they operate. These reports have taken the form of environmental accounting, which looks primarily at the environmental impacts expressed predominantly in qualitative terms. Triple-Bottom Line Accounting incorporates not only environmental impacts but also separately introduces social impacts and economic impacts of the company's performance. Sustainability Accounting has as its main aim, an integration of environmental, social and economic impact and the interaction between them (Christofi, Christofi \& Sisaye 2012:160). SR is designed to allow companies to disclose good and bad impacts on society and the environment and when linked to financial reporting by association, it can inherit the defects of untruthfulness and incompleteness (Schaltegger \& Burritt 2010:376). There are many differences between Financial and SR that make the two reporting mechanisms difficult to combine; however, the importance of the two is undeniable and therefore accountants have begun to consider the option for new reporting models (Arras \& Crowther 2009:283). The overall advantage for these new reporting models is linked to cost advantages from (1) an integrated reporting and communications strategy; (2) the need for a balanced picture of both the good and the bad news; (3) the extension to include social and environmental information with financial information and (4) improved confidence in the leadership of the company (Global Reporting Initiative 2011:3).

SR should not merely be public relations but should take into consideration the company's growth and competitiveness. However, if sustainability is incorporated in the company's goals, then what would be the metrics used to operationalise sustainability and how can these be communicated? The next two sections will give a brief overview of sustainability and FP indicators.

\section{Sustainability performance indicators}

Sustainable performance has been defined by Artiach et al. (2010:32) as 'the extent to which a firm embraces economic, environmental, social and governance factors into its operations and ultimately the impact they exert on the firm and society'.

In 2011, the Global Reporting Initiative (GRI) reported that 2304 SRs had incorporated the standardised GRI Framework for SD reporting into their SR. In 2013 the count had ballooned to 11004 reports from 4967 companies (Global Reporting Initiative 2013). The GRI produces one of the world's most prevalent standards for SR, and in promoting the use of these standardised metrics, GRI seeks to make SR by all organisations as routine as, and comparable to, financial reporting (Global Reporting Initiative 2013). The GRI's standard for SR is the international benchmark standard for corporate SR and is now the leading guideline for the reporting, control and measurement of sustainability performance with more than three quarters of the Global Fortune 250 companies using it. The use of GRI metrics by organisations is an indication of their commitment to SR and the philosophy that the triple-bottom line of social, environmental and economic impacts is gaining in varying degrees of importance (Hodgson \& Burke 2011:27). The GRI guidelines include 79 indicators for companies to report on their social, environmental and economic performance (Sarfaty 2013:1). Table 1 contains the abridged GRI performance indicators.

To date though, no single measure that can be used across international borders and across industries has been formalised as the standard (Pinter, Hardi \& Bartelmus 2005:6).

The JSE Socially Responsible Investment (SRI) Index is the first sustainability index developed in the emerging market nations. It was launched in May 2004. The main motivation behind the establishment of the index was to meet the need for companies in emerging markets to demonstrate socially responsible behaviour and embrace the triple-bottom lines of environmental, economic and social sustainability (Sonnenberg \& Hammann 2006). The SRI has three broad objectives: (1) to highlight good corporate sustainability performance of companies listed on the JSE All Share Index, (2) to provide the basis for financial SRI products, and lastly (3) to satisfy the need for an accepted and objective method of measuring sustainability performance of listed companies. Sonnenberg and Hamman (2006:306) conducted an assessment of the success of the SRI in achieving its objectives during its first 2 years of existence. The means of assessing sustainability performance relies significantly on selfdisclosure in the company's SRs (Sonnenberg \& Hamman 2006:306). The SRI is based on a set of 70 criteria or indicators grouped into four all-encompassing categories: corporate

TABLE 1: Abridged global reporting initiative performance indicators.

\begin{tabular}{|c|c|c|}
\hline Category & Description & \\
\hline \multirow[t]{4}{*}{ Social } & Labour practices & $\begin{array}{l}\text { Employment, labour management relations, } \\
\text { health and safety, training and education, } \\
\text { employment diversity and opportunity. }\end{array}$ \\
\hline & Human rights & $\begin{array}{l}\text { Investment practices, nondiscrimination, } \\
\text { child labour, disciplinary practices, security } \\
\text { practices, indigenous rights. }\end{array}$ \\
\hline & Society & $\begin{array}{l}\text { Community impact, public policy, } \\
\text { anticompetitive behaviour, compliance, } \\
\text { bribery and corruption, political } \\
\text { contributions. }\end{array}$ \\
\hline & Product responsibility & $\begin{array}{l}\text { Customer health and safety, product and } \\
\text { service labelling, marketing communication, } \\
\text { customer privacy, compliance. }\end{array}$ \\
\hline Economic & \multicolumn{2}{|c|}{$\begin{array}{l}\text { Competition and pricing, economic performance, market presence, } \\
\text { indirect economic impacts. }\end{array}$} \\
\hline Environmental & \multicolumn{2}{|c|}{$\begin{array}{l}\text { Materials, energy and water used, biodiversity, emissions, effluents } \\
\text { and waste, suppliers, products and service compliance, transport. }\end{array}$} \\
\hline
\end{tabular}


governance, society, environment and economy. The 70 criteria, whilst slightly lagging behind the Financial Times Stock Exchange and Dow Jones equivalents ( \pm 90 criteria), are designed for the particular South African environment and will be subject to further refinement/additions (e.g. The Congress of South African Trade Unions has called on greater focus on criteria relating to job creation). These refinements will have implications for corporate citizenship in South Africa and the African continent because many South African based companies are expanding into the rest of Africa. In order to be included on the index, companies must answer a questionnaire designed, administered and analysed by a private sustainability consultancy and a minimum score must be achieved (Sonnenberg \& Hamman 2006:309). A limitation and aspect of the index that has brought some criticism from the various sectors is that company performance is based on information (mostly qualitative in nature) supplied by the companies in their SRs. In order to avoid skewing results in the indicators by overestimation of actual performance, Sonnenberg and Hamman (2006:310) call for the use of additional sources of independent information because this will encourage companies to go beyond a checklist exercise. Research conducted by Bartels, Iansen-Rogers and Kuszewski (2008:17), Berthelot, Coulmont and Serret (2012:355) and Magness (2010:56) found that there is an interest in using the information contained in a company's SRs (in conjunction with financial reports) to guide investment decisions (Searcy and Elkhawas 2012:81).

From this literature, the hypothesis formulated for this study is: There is a positive relationship between sustainable development and FP in South African Companies.

\section{Financial performance indicators}

Financial statements provide valuable information to financial analysts who assess the FP and position of companies. However, when making comparisons between two or more companies because of the differences in size, monetary value and industry to which the company may belong, financial ratios are better used to evaluate relative performance of the companies over time (Du Toit et al. 2010:57). Forty-two standard financial ratios exist that are used to determine a companies' FP. These ratios can broadly be divided into four main categories, profitability, liquidity, solvency and efficiency. The financial ratios that are used to measure return on investment from its capital are known as profitability ratios (Du Toit et al. 2010:61) - amongst the most commonly used ratios are return on assets (ROAs), return on equity and return on shareholders' equity.

FP indicators are likely to lead investment analysts to make favourable assessments on the future performance of the company, which therefore should in turn lead to an increase in the value of the company's shares. To determine if companies which proactively pursue sustainability initiatives are better financial performers, it is essential to find a relationship between the identified FP indicators and higher sustainability performance (Ernst and Young 2012:27).

\section{The Link between sustainability and financial performance}

Salzmann et al. (2005:28) conducted research on whether sustainability performance is related to FP, from two broad perspectives, namely theoretical studies and empirical studies. The theoretical studies are grounded on frameworks that aim to explain the nature of the relationship between SD and FP. Empirical studies are based on two distinct approaches to the research: firstly, instrumental studies empirically test the hypothesis and secondly, descriptive studies gather qualitative information on how companies and managers approach SD initiatives. The theoretical studies highlighted by Salzmann et al. (2005:28) produced frameworks to explain the relationship between SD and FP and the difference between the frameworks lies in the hypothesised causal sequence and direction of the relationship. Table 2 shows the frameworks developed by various authors on the relationship between SD and FP and also provides the actual hypotheses and descriptions of what was attempted to be tested.

The research of Salzmann et al. (2005:29) aimed to test the relationship between SD and FP (shown in Table 2) using research design paths, namely case studies (through success stories and interviews) and quantitative studies (through

TABLE 2: Frameworks, hypotheses and descriptions of prior research to test the relationship between sustainable development and financial performance.

\begin{tabular}{|c|c|c|c|}
\hline Relationship type & Framework & Description & Researcher \\
\hline \multirow[t]{3}{*}{$\begin{array}{l}\text { Negative link between } \\
\text { SD and FP }\end{array}$} & $\begin{array}{l}\text { Trade-off hypothesis } \\
\text { (Higher SD causes lower FP) }\end{array}$ & $\begin{array}{l}\text { Based on Freidman's neo-classical argument that companies only have one } \\
\text { social responsibility (i.e. to increase profits). }\end{array}$ & Vance (1975) \\
\hline & $\begin{array}{l}\text { Managerial opportunism hypothesis } \\
\text { (Higher FP causes lower SD) }\end{array}$ & $\begin{array}{l}\text { Managers reduce SD spend when FP is strong to maximise personal gain } \\
\text { (i.e. linked to short-term FP). }\end{array}$ & $\begin{array}{l}\text { Posner and Schmidt (1992); } \\
\text { Alhafaji (1989) }\end{array}$ \\
\hline & Negative synergy & Combination of trade-off and managerial opportunism. & \\
\hline $\begin{array}{l}\text { Neutral link between } \\
\text { SD and FP }\end{array}$ & $\begin{array}{l}\text { Supply and Demand Theory } \\
\text { (No link between SD and FP) }\end{array}$ & $\begin{array}{l}\text { Companies customise level of Sustainable Development Initiatives to } \\
\text { maximise profits. }\end{array}$ & $\begin{array}{l}\text { Anderson and Frankle (1980); } \\
\text { Freedman and Jaggi (1982) }\end{array}$ \\
\hline \multirow[t]{3}{*}{$\begin{array}{l}\text { Positive link between } \\
\text { SD and FP }\end{array}$} & Social Impact Hypothesis & $\begin{array}{l}\text { Meeting the needs of nonowner stakeholders increases FP; failure to meet } \\
\text { needs leads to market fears (negative impact on company reputation), } \\
\text { increases risk and affects FP; Superior FP enables increase in SD performance. }\end{array}$ & $\begin{array}{l}\text { Pava and Krausz (1996); Preston } \\
\text { and O' Bannon (1997) }\end{array}$ \\
\hline & $\begin{array}{l}\text { Available funds hypothesis } \\
\text { (aka slack resources theory) }\end{array}$ & Superior FP allows companies to invest in Sustainable Development Initiatives. & $\begin{array}{l}\text { Kraft and Hage (1990); } \\
\text { Moore (2001) }\end{array}$ \\
\hline & Positive energy: 'Virtuous circle' & $\begin{array}{l}\text { Combination of slack resources and good management. Good management } \\
\text { will do most things well; therefore, FP and SD will be positively correlated. }\end{array}$ & $\begin{array}{l}\text { Preston and O' Bannon (1997); } \\
\text { Stanwick and Stanwick (1998) }\end{array}$ \\
\hline
\end{tabular}

Source: Adapted from Salzmann, O., lonescu-Somers, A. \& Steger, U., 2005, 'The business case for corporate sustainability: Literature review and research options', European Management Journal 23(1), 27-36. http://dx.doi.org/10.1016/j.emj.2004.12.007

SD, sustainable development; FP, financial performance. 
portfolio analysis, event studies and multivariate analyses). The qualitative approach had some weaknesses as the evidence is not 'hard enough' and also not comparable as often related to specific characteristics of a single industry (Salzmann et al. 2005:29). This research study followed the quantitative route as carried out by Montabon, Scroufe and Narashiman (2007) (more about this methodology will be dealt with in the Research Methodology section).

Salzmann et al. (2005:30) state that the prior research reviewed (before Montabon et al. (2007) added to the body of knowledge) was largely inconclusive on whether a relationship between SD and FP exists. The reasons for the inconclusive results were identified as (1) use of a wide variety of measures for performance on SD, (2) lack of studies to test definitions and concepts of SD, (3) lack of significance testing and control of interaction with multiple variables, (4) inadequate sampling techniques and lastly (5) use of a wide variety of FP measures. Salzmann et al. (2005:30) conclude by stating that the SD-FP relationship is complex and contingent on situational factors and company- and plant-specific factors, and for this reason, the direction of causality between SD and FP remains unresolved. The research design and approach taken by Montabon et al. (2007) resolves the issues detected in the previous studies as highlighted by Salzmann et al. (2005:30), and for this reason, our study will replicate the research methodology and design of the Montabon et al. (2007) study.

\section{Research methodology}

Our research study replicates the research design and methodology of Montabon et al. (2007) titled 'An examination of corporate reporting, environmental management practices and company performance' within the South African context. The study will extend the research of Montabon et al. (2007) by including the social factor of the triple-bottom line. Permission to replicate the study has been granted.

The research was designed as a formal study that consisted of a literature review and an empirical study. The time dimension of the research was cross-sectional and followed a mixed method approach. The research study aimed to determine whether a relationship between sustainable development initiatives and improved company FP exists. This implies that a base measurement of FP must be found and improvements against this base in subsequent measures ascertained. This research study followed a philosophical paradigm that is positivistic and interpretive in nature, because the study assessed the level of involvement that companies have in the identified sustainability initiatives.

The population was all companies that were listed on the JSE between 2012 and 2013. The parameter of interest of the study was sustainable development performance (as derived from the SRs) and FP (as derived from the financial reports), which can be found in the annual reports of the listed companies.
The data collection had three steps. Firstly, a systematic random selection of 45 listed companies on the JSE was carried out. The Financial Mail was used to identify 45 listed companies that published their annual reports in the Financial Mail. The 45 companies were chosen to be in-line with the study of Montabon et al. (2007), who had also used 45 companies, from various industries in their study. The industry to which these companies belong was not important; therefore, there were no representative sample from each industry.

Table 3 contains the 45 listed companies that were selected and whose SRs have been kept for analysis.

Secondly, an online search for each company's SR was performed. Although South African companies are not yet obliged to present a separate SR, most have these already in place; therefore, these reports were used in the research study. Thirdly, quantitative content analyses of the SRs were carried out based on the variables used by Montabon et al. (2007). Montabon et al. (2007) identified the following sustainable development initiatives (divided into four broad categories): Operational (recycling, waste reduction proactive, waste reduction reactive, remanufacturing, substitution, consume internally, packaging, spreading risk, market for waste, energy, money spent on environment, environmental information and rewards); Tactical (supply chain management, early supplier involvement; environmental standard for suppliers, environmental audits of suppliers, environmental awards/recognition, environmental participation, use of life cycle analysis or design for environment, product development and innovation, design, specific design targets, environmental risk analysis, environmental management systems and communication with stakeholders as to the environmental impacts of the company on the environment); Strategic (integration with long-term business strategy, corporate policies and procedures, environmental mission statement, employee programmes, environmental department/teams, surveillance of the market for environmental issues and strategic alliances); Performance measures (reduction in significant environmental incidents, environmental certification, continuous improvement, recycling performance, customer and shareholder perception of environmental performance, independent audits of environmental performance, waste

TABLE 3: List of companies that form the sample for the research.

\begin{tabular}{llll}
\hline Company & Company & Company & Company \\
\hline ABSA & Discovery & Mondi & Rainbow \\
Adcock & Distell & MTN & SAB Miller \\
AFGRI & DRD Gold & Multichoice & Sanlam Ltd \\
Afrox & Exxaro & Nampak & Sappi Ltd \\
Anglo American & Grindrod & Netcare & Sasol \\
Arcelor Mittal & Harmoy & Oceana & Standard Bank \\
Aspen & Illovo & Old Mutual & Steinhoff International \\
Astral Foods & Implats & Omnia & The Bidvest Group \\
AVI & Lonmin & Pick n Pay & Vodacom \\
Barloworld & Massmart & Pioneer Foods & Woolworths \\
BHP Biliton & Merafe & PPC Ltd & York \\
Clover & - & & \\
\hline
\end{tabular}


reduction, resource consumption, cost savings for environmental projects and activities, ROAs, return on investments, operating earnings, sales growth, innovation performance of products and innovation performance of processes).

Montabon et al. (2007) compiled a rating sheet based on the sustainable development initiatives. The rating sheet compiled by Montabon et al. (2007) required validation and extension for the South African context to ensure that the measures were applicable and include the social initiatives of sustainable development (see Appendix A). Validation and extension of the rating sheet used by Montabon et al. (2007:1006) were carried out by using quantitative content analysis of the SR's. This resulted in the extension of the Montabon et al. (2007:1012-1013) rating sheet to include the social upliftment initiatives of enterprise development, corporate social investment and transformation. The rating was performed by two raters with experience in the field of sustainability. Raters used the list of definitions for each SD initiative as compiled by Montabon et al. (2007:1010-1011) and the rating sheet (Annexure A) to do the ratings. Each company's sustainable development performance was rated by giving a score on a 5 -point Likert scale, where 1 indicates low intensity of involvement and 5 indicates high intensity of involvement in the specific initiative. The list of definitions (Montabon et al. 2007:1012-1013) also gave guidelines to assist with determining the level of involvement. This enabled the raters to allocate a score. The researcher and the rater used coding sheets and captured the ratings in a database. The ratings were carried out independently - each rater independently assigned a value to each sustainable development initiative. The scores for each company on the sustainable development initiatives formed the independent variables (IV). The dependent variables (DVs) were measures of FP, namely revenue growth, return on investment, ROAs and product or process innovations.

\section{Interrater reliability}

Interrater reliability is required to ensure that the data that have been gathered are robust enough to withstand the statistical analysis used to test the correlation. Interrater reliability is primarily performed whereby the aim is to test whether the ratings for the DVs gathered by the two raters are in agreement or are correlated with each other for each company forming part of the sample.

To test interrater reliability, hypothesis testing was used. The null hypothesis is as follows: There is no agreement between the scores of the two raters. For this test, a test statistic is used and the corresponding $p$-value of the test statistic will determine whether the scores for each variable are correlated with each other. The standard degree of freedom that is used for this is typically $5 \%$ or 0.05 , and therefore $p$-values that are greater than or equal to 0.05 ( $p \geq 0.05$ ) will mean that the null hypothesis cannot be rejected. If the $p$-value is less than $0.05(p<0.05)$, then one can reject the null hypothesis and accept the alternative hypothesis.

The results of the interrater reliability test are presented in Table 4. The reliability of the scores for the IVs is not necessary as these scores were obtained by calculations directly from the financial results contained in the company's annual reports and are therefore not subject to differing interpretation. In order to convert the scores for the financial ratio calculations of ROI, ROA, Revenue Growth and Profit

TABLE 4: Results of test of interrater reliability for 'Sig' dependent variables.

\begin{tabular}{|c|c|c|c|c|c|c|c|}
\hline \multirow[t]{2}{*}{ Variables } & \multirow[t]{2}{*}{ Intraclass Correlation ${ }^{\mathrm{a}}$} & \multicolumn{2}{|c|}{ 95\% Confidence Interval } & \multicolumn{4}{|c|}{$F$-test with True Value 0} \\
\hline & & Lower Bound & Upper Bound & Value & df1 & df2 & Sig \\
\hline Communication & 0.851 & 0.743 & 0.915 & 12.139 & 44 & 44 & 0.000 \\
\hline Corporate social investment & 0.859 & 0.759 & 0.920 & 13.066 & 44 & 44 & 0.000 \\
\hline Cost savings & 0.873 & 0.781 & 0.928 & 14.598 & 44 & 44 & 0.000 \\
\hline Customer perception & 0.892 & 0.812 & 0.939 & 17.272 & 44 & 44 & 0.000 \\
\hline Employee programmes & 0.878 & 0.789 & 0.931 & 15.126 & 44 & 44 & 0.000 \\
\hline Energy & 0.853 & 0.747 & 0.916 & 12.329 & 44 & 44 & 0.000 \\
\hline Health and safety / HIV & 0.863 & 0.764 & 0.923 & 13.364 & 44 & 44 & 0.000 \\
\hline Long-term interest & 0.821 & 0.696 & 0.897 & 10.465 & 44 & 44 & 0.000 \\
\hline Product development / innovations & 0.942 & 0.897 & 0.968 & 33.463 & 44 & 44 & 0.000 \\
\hline Reduction in incidents & 0.908 & 0.840 & 0.948 & 20.837 & 44 & 44 & 0.000 \\
\hline Remanufacturing & 0.957 & 0.923 & 0.976 & 44.644 & 44 & 44 & 0.000 \\
\hline Resource consumption & 0.885 & 0.800 & 0.935 & 16.089 & 44 & 44 & 0.000 \\
\hline SCM & 0.911 & 0.843 & 0.950 & 21.025 & 44 & 44 & 0.000 \\
\hline Spreading risk & 0.896 & 0.818 & 0.941 & 17.960 & 44 & 44 & 0.000 \\
\hline Strategic alliance & 0.908 & 0.839 & 0.948 & 20.414 & 44 & 44 & 0.000 \\
\hline Substitution & 0.890 & 0.808 & 0.938 & 17.927 & 44 & 44 & 0.000 \\
\hline Surveillance of market & 0.899 & 0.820 & 0.944 & 20.007 & 44 & 44 & 0.000 \\
\hline Waste reduction & 0.869 & 0.775 & 0.926 & 14.378 & 44 & 44 & 0.000 \\
\hline Waste reduction (proactive) & 0.888 & 0.806 & 0.937 & 16.697 & 44 & 44 & 0.000 \\
\hline
\end{tabular}

Two-way mixed effects model where people effects are random and measures effects are fixed.

a, Type A intraclass correlation coefficients using an absolute agreement definition. The estimator is the same, whether the interaction effect is present or not. 
Growth into a level of involvement score on the 5-point Likert-type scale, the scores for the companies were standardised, with the highest score achieved being the upper limit of the scale and therefore being given the rating of 5. The lowest score on each ratio was given the score of 1 and all other scores then falling between these, the upper and lower limit, were rounded to no decimal places. Table 4 shows that all DVs selected as 'sig' have $p$-test statistics less than $0.05(p<0.05)$, and therefore, the null hypothesis can be rejected and the alternate hypothesis accepted. Therefore, it can be concluded that the data gathered by the two raters are reliable. One can also use the intraclass correlation coefficient to assess how closely the scores of the two raters are correlated. Cronbach's alpha is used (refer to column 2 - 'Intraclass Correlation'); an alpha of 1 means that the two scores are exactly correlated and a one-to-one relationship exists. An acceptable level for Cronbach's alpha to assume reliability is 0.7 (Cortina 1993: 100), the lowest alpha value for the selected DVs is 0.82 with the highest being 0.94 .

\section{Test of normality}

Table 5 shows the results of the test of normality using Shapiro-Wilk. The results for Shapiro-Wilk show that all $p$-values are less than $0.05(p \leq 0.05)$, and it can therefore be concluded that the data come from a normal distribution.

The data analysis was carried out with the use of Canonical Correlation Analysis (a multivariate regression analysis method) to determine if a relationship exists between sustainable development initiatives and company FP. The six stages of Canonical Correlation Analysis according to Hair et al. (1998:8) were used (these six stages will be dealt with in the Results section).

\section{Results}

As indicated previously, 45 companies, from various industries, were selected as sample for this study (refer to Table 3). Table 5 contains the descriptive statistics of mean, median, mode, standard deviation and minimum and maximum for the mean scores of the two raters. Table 6 shows that there are no missing data, and for all the measures of SD and FP, there is a wide range of levels of involvement for the companies within the sample.

From Table 6 the mean scores for the level of involvement for the variables lie mostly at the midpoint of the 5-point scale, the highest mean score is for Corporate Social Responsibility (3.47) and the lowest is for Environmental Awards (2.11). These scores may be because of Corporate Social Responsibility being an overarching term that can be used to group multiple SD initiatives, whilst Environmental Awards are quite specific. In addition to this, the development of awards from the environmental interest bodies may be less developed in South Africa in comparison to other markets in the world.
TABLE 5: Test of normality on significant independent and dependent variables.

\begin{tabular}{lccc}
\hline Independent Variables & \multicolumn{3}{c}{ Shapiro-Wilk } \\
\cline { 2 - 4 } & Statistic & Df & Sig \\
\hline Waste reduction (Proactive) & 0.919 & 45 & 0.004 \\
Remanufacturing & 0.855 & 45 & 0.000 \\
Substitution & 0.828 & 45 & 0.000 \\
Spreading risk & 0.895 & 45 & 0.001 \\
Recycling & 0.916 & 45 & 0.003 \\
Supply chain management & 0.886 & 45 & 0.000 \\
Product development / innovations & 0.821 & 45 & 0.000 \\
Communication & 0.917 & 45 & 0.003 \\
Long-term interest & 0.940 & 45 & 0.022 \\
Waste reduction (reactive) & 0.949 & 45 & 0.047 \\
Surveillance of market & 0.830 & 45 & 0.000 \\
Strategic alliance & 0.890 & 45 & 0.000 \\
Skills development & 0.940 & 45 & 0.021 \\
Health and safety / HIV & 0.911 & 45 & 0.002 \\
Corporate social investment & 0.892 & 45 & 0.001 \\
Reduction in incidents & 0.834 & 45 & 0.000 \\
Customer perception & 0.903 & 45 & 0.001 \\
Waste reduction & 0.941 & 45 & 0.024 \\
Resource consumption & 0.931 & 45 & 0.010 \\
Cost savings & 0.936 & 45 & 0.015 \\
Return on assets & 0.889 & 45 & 0.000 \\
Substitution & 0.889 & 45 & 0.000 \\
Innovation product & 0.841 & 45 & 0.000 \\
Innovation process & 0.851 & 45 & 0.000 \\
\hline & & & \\
\hline
\end{tabular}

\section{Canonical correlation analysis}

Six stages according to Hair et al. (1998:7) were followed in the canonical correlation analysis.

Firstly, the objectives of the canonical correlation analysis were established (DVs and IVs). The IVs are the sustainable development initiatives and the DVs of the FP indicators (ROA, ROI, Revenue Growth, Product and Process Innovation). These FP indicators were selected to be in-line with the FP indicators selected by Montabon et al. (2007).

Secondly, the canonical correlation analysis was designed. To ensure that the statistical technique can be performed to attain answers to the research questions, a similar methodology as employed by Montabon et al. (2007:1005) was used. Montabon et al. (2007:1005) reduced the number of variables from 48 to 20 based on their own judgement (a priori). This is carried out (in addition to the sample requirements for the statistical analysis) to ensure that the specification of the variable sets was based on a strong conceptual foundation (Hair et al. 1998). Table 7 shows the 20 DVs used on the South African companies.

This stepwise procedure is performed to eliminate variables and to ensure that the final analysis is closer to the recommended number of observations per variable (Hair et al. 1998:6). The procedure that was used is as follows:

- $20 \mathrm{IVs}$ were assumed to be significant and put into a group referred to as 'sig'.

- The IV and DVs were entered into Canonical Correlation Analysis. 
TABLE 6: Mean descriptive statistics of independent and dependent variables.

\begin{tabular}{|c|c|c|c|c|c|c|c|c|}
\hline \multirow[t]{2}{*}{ Variables } & \multicolumn{2}{|c|}{$N$} & \multirow[t]{2}{*}{ Mean } & \multirow[t]{2}{*}{ Median } & \multirow[t]{2}{*}{ Mode } & \multirow{2}{*}{$\begin{array}{l}\text { Standard } \\
\text { deviation }\end{array}$} & \multirow[t]{2}{*}{ Minimum } & \multirow[t]{2}{*}{ Maximum } \\
\hline & Valid & Missing & & & & & & \\
\hline \multicolumn{9}{|l|}{ Operational practices } \\
\hline Recycling & 45 & 0 & 2.9667 & 3.5000 & 3.00 & 1.35848 & 1.00 & 5.00 \\
\hline Waste reduction (Proactive) & 45 & 0 & 3.0778 & 3.0000 & $1.00^{\mathrm{a}}$ & 1.33551 & 1.00 & 5.00 \\
\hline Waste reduction (Reactive) & 45 & 0 & 2.9778 & 3.0000 & 4.00 & 1.26111 & 1.00 & 5.00 \\
\hline Remanufacturing & 45 & 0 & 2.6333 & 2.0000 & 1.00 & 1.50906 & 1.00 & 5.00 \\
\hline Substitution & 45 & 0 & 2.1444 & 1.0000 & 1.00 & 1.27307 & 1.00 & 5.00 \\
\hline Consume internally & 45 & 0 & 2.2444 & 2.0000 & 1.00 & 1.33834 & 1.00 & 5.00 \\
\hline Packaging & 45 & 0 & 2.3000 & 1.0000 & 1.00 & 1.54993 & 1.00 & 5.00 \\
\hline Spreading risk & 45 & 0 & 2.6556 & 2.0000 & 1.00 & 1.38508 & 1.00 & 5.00 \\
\hline Market for waste & 45 & 0 & 2.1778 & 2.0000 & 1.00 & 1.23470 & 1.00 & 5.00 \\
\hline Energy & 45 & 0 & 3.3111 & 3.0000 & 3.00 & 1.18364 & 1.00 & 5.00 \\
\hline Money spent on environment & 45 & 0 & 2.7333 & 2.0000 & 1.00 & 1.33825 & 1.00 & 5.00 \\
\hline Environmental information & 45 & 0 & 2.4111 & 2.0000 & 1.00 & 1.23532 & 1.00 & 5.00 \\
\hline \multicolumn{9}{|l|}{ Tactical practices } \\
\hline Supply chain management & 45 & 0 & 2.9111 & 3.0000 & 1.00 & 1.46275 & 1.00 & 5.00 \\
\hline Early supplier involvement & 45 & 0 & 2.2222 & 1.0000 & 1.00 & 1.21335 & 1.00 & 4.50 \\
\hline Environmental standard for suppliers & 45 & 0 & 2.3111 & 1.0000 & 1.00 & 1.47050 & 1.00 & 5.00 \\
\hline Environmental audits suppliers & 45 & 0 & 2.5667 & 2.0000 & 1.00 & 1.50982 & 1.00 & 5.00 \\
\hline Environmental awards & 45 & 0 & 2.1111 & 1.5000 & 1.00 & 1.35634 & 1.00 & 5.00 \\
\hline Environmental participation & 45 & 0 & 2.9000 & 3.0000 & 1.00 & 1.33825 & 1.00 & 5.00 \\
\hline Life cycle analysis & 45 & 0 & 1.6000 & 1.0000 & 1.00 & .95703 & 1.00 & 5.00 \\
\hline Product development / innovations & 45 & 0 & 2.6889 & 2.0000 & 1.00 & 1.61065 & 1.00 & 5.00 \\
\hline Design & 45 & 0 & 2.6556 & 2.0000 & 1.00 & 1.33494 & 1.00 & 5.00 \\
\hline Design targets / goals & 45 & 0 & 2.7556 & 2.0000 & 1.00 & 1.49477 & 1.00 & 5.00 \\
\hline Environmental risk analysis & 45 & 0 & 2.9889 & 3.0000 & 5.00 & 1.40004 & 1.00 & 5.00 \\
\hline Environmental management systems & 45 & 0 & 3.5778 & 4.0000 & 5.00 & 1.30973 & 1.00 & 5.00 \\
\hline Communication & 45 & 0 & 2.9000 & 2.0000 & $1.00^{\mathrm{a}}$ & 1.31253 & 1.00 & 5.00 \\
\hline Corporate policies and procedures & 45 & 0 & 3.3778 & 3.0000 & 3.00 & 1.01777 & 1.00 & 5.00 \\
\hline Environmental mission statement & 45 & 0 & 2.5556 & 2.0000 & 1.00 & 1.31522 & 1.00 & 5.00 \\
\hline Employee programmes & 45 & 0 & 3.0333 & 3.0000 & 3.00 & 1.20793 & 1.00 & 5.00 \\
\hline Environmental department & 45 & 0 & 2.1222 & 1.0000 & 1.00 & 1.28433 & 1.00 & 5.00 \\
\hline Surveillance of market & 45 & 0 & 2.1222 & 2.0000 & 1.00 & 1.16363 & 1.00 & 4.50 \\
\hline Strategic alliance & 45 & 0 & 2.8444 & 3.0000 & 1.00 & 1.44136 & 1.00 & 5.00 \\
\hline \multicolumn{9}{|l|}{ Social upliftment Initiatives } \\
\hline Enterprise development & 45 & 0 & 3.1333 & 3.0000 & 5.00 & 1.39153 & 1.00 & 5.00 \\
\hline Transformation & 45 & 0 & 3.4556 & 3.0000 & 3.00 & 1.21927 & 1.00 & 5.00 \\
\hline Skills development & 45 & 0 & 3.2889 & 3.0000 & $3.00^{\mathrm{a}}$ & 1.17012 & 1.00 & 5.00 \\
\hline Health and safety / HIV & 45 & 0 & 3.0000 & 2.0000 & 2.00 & 1.29246 & 1.00 & 5.00 \\
\hline Corporate social investment & 45 & 0 & 3.4778 & 3.0000 & 5.00 & 1.30103 & 1.00 & 5.00 \\
\hline \multicolumn{9}{|c|}{ Environmental or financial or market performance } \\
\hline Reduction in incidents & 45 & 0 & 2.1778 & 2.0000 & 1.00 & 1.27099 & 1.00 & 5.00 \\
\hline Environmental certification & 45 & 0 & 2.7667 & 2.0000 & $1.00^{\mathrm{a}}$ & 1.35512 & 1.00 & 5.00 \\
\hline Continuous improvement & 45 & 0 & 2.8111 & 2.0000 & $1.00^{\mathrm{a}}$ & 1.29811 & 1.00 & 5.00 \\
\hline Recycling performance & 45 & 0 & 2.8778 & 3.0000 & 1.00 & 1.36163 & 1.00 & 5.00 \\
\hline Customer perception & 45 & 0 & 3.0222 & 3.0000 & 4.00 & 1.39787 & 1.00 & 5.00 \\
\hline Independent audits & 45 & 0 & 2.8889 & 3.0000 & 1.00 & 1.33096 & 1.00 & 5.00 \\
\hline Waste reduction & 45 & 0 & 2.7667 & 2.0000 & 2.00 & 1.22753 & 1.00 & 5.00 \\
\hline Resource consumption & 45 & 0 & 3.3333 & 3.0000 & 4.00 & 1.20605 & 1.00 & 5.00 \\
\hline Cost savings & 45 & 0 & 2.9444 & 3.0000 & 4.00 & 1.24874 & 1.00 & 5.00 \\
\hline Return on assets & 45 & 0 & 3.0000 & 3.0000 & $1.00^{\mathrm{a}}$ & 1.43019 & 1.00 & 5.00 \\
\hline Return on investment & 45 & 0 & 3.0000 & 3.0000 & $1.00^{\mathrm{a}}$ & 1.43019 & 1.00 & 5.00 \\
\hline Operating earnings & 45 & 0 & 3.0000 & 3.0000 & $1.00^{\mathrm{a}}$ & 1.43019 & 1.00 & 5.00 \\
\hline Sales growth & 45 & 0 & 3.0000 & 3.0000 & $1.00^{\mathrm{a}}$ & 1.43019 & 1.00 & 5.00 \\
\hline Innovation product & 45 & 0 & 2.9556 & 3.0000 & 1.00 & 1.58050 & 1.00 & 5.00 \\
\hline Innovation process & 45 & 0 & 2.8667 & 3.0000 & 1.00 & 1.53149 & 1.00 & 5.00 \\
\hline
\end{tabular}

a, Multiple modes exist. The smallest value is shown. 
- The IV found not to be significant were removed from the 'sig' and put into a group labelled 'non-sig'.

- Steps two and three are repeated.

- The IVs in group 'non-sig' and DVs are entered into canonical correlation function. The significant IVs are removed from 'non-sig' and entered into 'sig'.

- Steps two to five are repeated until there are no changes between 'non-sig' and 'sig'.

The final result of the stepwise analysis resulted in six IVs being significantly correlated with the four DVs (indicated with an asterisk (*) in Table 7).

For the third stage, assumptions of canonical correlation were made. The important underlying statistical assumptions of Canonical Correlation Analysis are linearity of the variables and the normality of the variables. According to Hair et al. (1998:6), the assumption of linearity affects two aspects of canonical correlation results. Firstly, the correlation coefficient between any two variables is based on a linear relationship. If the relationship is nonlinear, then one or both

\begin{tabular}{|c|c|}
\hline $\begin{array}{l}\text { Common significant sustainability } \\
\text { intiatives }\end{array}$ & $\begin{array}{l}\text { Different significant sustainability } \\
\text { initiatives }\end{array}$ \\
\hline Proactive waste reduction $(2) \dagger$ & Communication (26) \\
\hline Remanufacturing (4) & Corporate social investment (38) \\
\hline Surveillance of market $(32) \dagger$ & Cost savings (47) \\
\hline \multirow[t]{13}{*}{ Strategic alliance (33) } & Customer perception (43) $\dagger$ \\
\hline & Employee programmes (30) \\
\hline & Energy (10) \\
\hline & Health and safety / HIV (37) \\
\hline & Long-term interest $(27) \dagger$ \\
\hline & Product development innovation (21) \\
\hline & Reduction in incidents (39) \\
\hline & Resource consumption (46) \\
\hline & Skills development (36) \\
\hline & Spreading risk $(8) \dagger$ \\
\hline & Substitution (5) \\
\hline & Supply chain management (14) \\
\hline & Waste reduction (45) \\
\hline
\end{tabular}

Number in brackets refers to the number of sustainable initiatives on the rating sheet. $\dagger$, Six IVs being significantly correlated with the four DVs. variables should be transformed, if possible. Secondly, the canonical correlation is the linear relationship between the variates. If the variates relate in a nonlinear manner, the relationship will not be captured by canonical correlation. Thus, whilst canonical correlation analysis is the most generalised multivariate method, it is still constrained to identifying linear relationships.

In the fourth stage, canonical functions had to be derived. Successive pairs of canonical variates are based on residual variance, and their respective canonical correlations (which reflect the interrelationships between the variates) become smaller as each additional function is extracted. The first three canonical functions are considered, because the fourth canonical function's Bartlett test of residual correlation ( $p$-value) is greater than the normal cut-off of 0.05 (Hair et al. 1998:8). The results for the canonical functions are shown in Table 8 .

A $p$-value less than $0.05(p<0.05)$ is deemed significant, and therefore, the first three canonical functions were significant.

Stage five interprets the canonical variates. For the first three functions (as these are significant), the canonical correlations can be interpreted by their Eigen values. The canonical correlation for the first (0.956), second (0.726) and third (0.608) function has high correlations. All these correlations are also positive, which means that if the IV scores increase, the scores of the DVs also increase. This therefore supports the hypothesis that there is a positive relationship between sustainable development performance and FP. Each of the IVs has differing degrees of correlation with the canonical variates; however, overall there is a positive relationship.

The final stage of the canonical correlation analysis is the validation of the analyses. The stepwise procedure employed has indicated that this validation of the IVs is not required because of the significance that has already been established (Hair et al. 1998:17).

TABLE 8: Canonical correlations and loadings.

\begin{tabular}{|c|c|c|c|c|}
\hline Variables & First canonical function & Second canonical function & Third canonical function & Fourth canonical function \\
\hline Canonical correlation (Eigenvalues) & 0.956 & 0.726 & 0.608 & 0.297 \\
\hline Bartlett test of residual correlations ( $p$-value) & 0.000 & 0.000 & 0.006 & 0.315 \\
\hline \multicolumn{5}{|l|}{ Canonical loading of independent variables } \\
\hline Proactive waste reduction & 0.199 & 0.022 & -1.022 & -0.531 \\
\hline Spreading risk & -0.194 & 0.104 & -0.096 & 0.244 \\
\hline Product development / innovations & -0.393 & -0.663 & 0.165 & 0.227 \\
\hline Long-term interest & -0.795 & 0.697 & 0.171 & -0.238 \\
\hline Surveillance of market & -0.092 & 0.477 & -0.004 & 0.943 \\
\hline Customer perception & -0.226 & -0.058 & 0.557 & -0.629 \\
\hline Redundancy indices & 0.713 & 0.161 & 0.051 & 0.074 \\
\hline \multicolumn{5}{|l|}{ Canonical loading of dependent variables } \\
\hline Return on assets & -0.127 & 0.558 & 0.550 & 0.769 \\
\hline Operating earnings growth & -0.003 & 0.432 & 0.031 & -0.984 \\
\hline Product innovation & -0.476 & -0.795 & 0.879 & -0.282 \\
\hline Redundancy indices & 0.652 & 0.085 & 0.019 & 0.007 \\
\hline
\end{tabular}




\section{Discussion of results}

This research supports the study by Porter and van der Linde (1995:98), who found that the trade-off between sustainable business practices and competitiveness is not absolute. It was stated that in many instances, pressures to adopt sustainable development practices can lead to a 'win-win' situation when companies react positively and proactively to find new and innovative ways to adapt. The findings in this research confirm that product and process innovation can lead to improved FP, and therefore, 'innovation offsets' (as coined by Porter and van der Linde [1995]), are evident in the South African companies that formed part of the sample.

Reed (2001:1) challenged conventional thinking that investment in sustainability initiatives adversely affects company profits. Reed's research focused on proving the Business Case for Sustainability Strategies and highlighted specific benefits like cost improvement, innovation and efficiency, as well as intangible assets such as reputation and employee goodwill that can translate into financial benefits for the company. The results of this research also support the findings of Reed (2001), specifically the initiatives that are aimed to deliver efficiencies and reputational benefits from customer perceptions.

The results of the research found that six of the IVs of the 20 sustainability initiatives are significantly related to FP in South African Companies and the nature of this relationship is positive. The FP indicators ROA, ROI, and Product Innovation and Process Innovation were identified as relevant FP indicators.

There is also a positive link between sustainable development performance and FP. It was found that six sustainable development initiatives that were included in the IV set are significant predictors of FP, namely proactive waste management, surveillance of the market, product development and innovations, long-term interest, spreading risk and customer perception.

Proactive Waste Management: This initiative measures the degree to which a company proactively reduces waste and/ or the elimination of waste before it is produced. The financial benefit for companies lies in the reduction of costs, which ultimately has an impact on profit.

Surveillance of the Market: This measure identified companies that look for opportunities in the market to select opportunities for environmentally and socially responsible practices in an attempt to identify future demand opportunities linked to environmentally friendly products and processes and thereby gain first entry benefits.

Product Development/Innovations: This initiative identifies companies that have been proactive in developing products that not only comply with regulations but are also environmentally friendly and reduce costs. This initiative is linked to the proposed innovation offsets by Porter and van der Linde (1995) that are included in the DV set. However, the initiative is a significant predictor of the dependent set as a whole and not only of the proposed innovation offsets.

Long-term interest: This initiative identifies companies that have explicitly stated in their sustainable development reports that the focus of their sustainable development practices are on long-term benefit to the environments and communities within which they operate, and these have been included in the strategic focus of the company. The long-term focus implies that the company is willing to forfeit short-term profits in the interest of long-term sustainable development.

Spreading Risk: This sustainable development initiative is common to companies which actively seek collaborative relationships with partners aimed at ensuring that the risk to the environment and communities is minimised and shared. This initiative can lead to companies which are risk averse to be more inclined to invest in sustainable development initiatives, and therefore, costs involved in the investment are also reduced. Companies that spread the risk also enlist the help of third parties to manage environmental risk.

Customer Perception: This initiative is linked to the corporate reputation management aspect of the sustainable development where benefits related to a customer's choice of which company's products or services to purchases is determined based on the perception of how the company gives back to the communities and environments where it operates. The reputational benefits can translate into increased sales and therefore improvement in the top line.

From the analysis it was evident that South African companies have a high focus on social upliftment initiatives aimed at improving Broad-Based Black Economic Empowerment scores. This is a regulation that has been imposed on South African companies because of the need to correct the imbalances in wealth caused by segregation of the population by race and ethnicity. Whilst these initiatives were found to be widespread, the five elements of social upliftment included on the Broad-Based Black Economic Empowerment scorecard and included in the IV set, were not found to be significant predictors of FP. It was also posed as to whether companies are bold enough to forfeit efficiency and short-term gains in favour of long-term altruistic actions that may provide the benefits they seek at an indefinite future date. It was found that companies that report that their sustainable development initiatives have a long-term focus produced better FP results than companies in the sample set who did not report this. This implies that companies that are forfeiting short-term efficiencies and gains in light of well-constructed strategic sustainable development initiatives are better financial performers.

The results of the research provide support that the business case for sustainable development does exist. It has been 
proven that high involvement and focus on specific sustainable development initiatives that are integrated into overall sustainable development strategies can deliver improved FP for the organisation and therefore deliver longterm value to its shareholders.

\section{Conclusion and recommendations}

Sustainable development is important for the well-being of the environment and humanity. Companies now actively pursue initiatives to enhance sustainability performance, ensuring that corporate reputation is improved. The aim of this study was to determine the relationship between sustainable development initiatives and company FP of South African listed companies. The results provide evidence that there is a business case (an alignment of social, environmental and social outcomes with FP, Hahn et al. 2015:21) for companies to focus on SD because it can translate into financial rewards.

It is recommended that South African companies take a proactive approach to sustainable development and openly disclose the actions taken to improve the environmental and societal aspects of the markets in which they operate. These disclosures will gain importance in the overall assessment of the financial health of the company.

It is recommended that the six aspects founded to be significantly correlated with improved FP be incorporated into the company's sustainable development strategy and that regulatory bodies and the South African government are engaged to assist in enhancement of the initiatives. The success of the sustainable development initiatives are not only to the company's benefit but also benefit the environment and societies of the home country and for this reason a collaborative effort will enhance success. The South African government's main focus is on the development of previously disadvantaged communities, and therefore, South African companies' sustainable development strategies should have people development as one of its core pillars.

Sustainable development is focused on the long-term and is based on the preservation and care for natural resources and humanity to ensure that future generations' needs are met. The South African market is an emerging market economy and the development of initiatives is not as advanced as markets in North America and Europe. However, South African companies are adopting the new international measures of sustainable development reporting, such as the GRI guidelines. The South African Stock Exchange has also established the SRI that has mimicked the DJSI and the FTSE4Good Index, and South African companies are ensuring that they satisfy the extensive criteria to gain membership to the index.

It is recommended that a longitudinal study is undertaken to draw comparisons between companies that are members of the sustainability indices and those that are not. As an alternative to this, how the companies that have gained membership and have improved their SR and measurement over time have performed on FP over the same period can be established. The longitudinal design may also ensure that research spans a period of both the upturn and downturn of the cyclical nature of market performance, and therefore, more clarity can be gained on the prioritisation of sustainability initiatives when profits and revenue or profit growth are under slightly higher pressure.

Lastly, it is also recommended that (as the study employed a similar research methodology as Montabon et al. 2007) a comparison is drawn between the two studies to determine how South African listed companies compare to North American listed companies.

The ultimate goal of sustainability is to ensure that future generations' needs are not compromised for short-term gain. This goal needs to be honoured to the benefit of not only South Africa but to all who live on this planet.

\section{Acknowledgements Competing interests}

The authors declare that they have no financial or personal relationship(s) that may have inappropriately influenced them in writing this article.

\section{Authors' contributions}

Both authors (D.G. and J.P.) contributed equally to the research and writing of this article.

\section{References}

Arras, G. \& Crowther, D., 2009, 'Corporate Sustainability Reporting: A Study in Disingenuity?' Journal of Business Ethics 87, 279-288. http://dx.doi.org/10.1007/ s10551-008-9806-0

Artiach, T., Lee, D., Nelson, D. \& Walker, J., 2010, 'The determinants of corporate sustainability performance', Accounting and Finance 50 (1), 31- 51. http://dx.doi. org/10.1111/j.1467-629X.2009.00315.x

Bartels, W., lansen-Rogers, J. \& Kuszewski, J., 2008, Count me in: The readers' take on sustainability reporting, KPMG and sustainability, viewed n.d., from https://www. globalreporting.org/resourcelibrary/Count-Me-In-The-Readers-take-onSustainability-Reporting.pdf

Berthelot, S., Coulmont, M. \& Serret, V., 2012, 'Do investors value sustainability reports? A Canadian study', Corporate Social Responsibility and Environmental Management 19(6), 355-363. http://dx.doi.org/10.1002/csr.285

Brundtland, G., 1987, The Brundtland Report: Our common future. New York: United Nations World Commission on Environment and Development, viewed n.d., from http://www.un-documents.net

Christofi, A., Christofi, P. \& Sisaye, S., 2012, 'Corporate sustainability: Historical development and reporting practices', Management Research Review 35 (2), 157-172. http://dx.doi.org/10.1108/01409171211195170

Cortina, J.M., 1993, 'What is coefficient alpha? An examination of theory and applications', Journal of Applied Psychology 78(1), 98-104. http://dx.doi. org/10.1037/0021-9010.78.1.98

Dimitrov, .D.K. \& Davey, H., 2011, 'Sustainable development: what it means to CFOs of New Zealand', Asian Review of Accounting 19 (1), 86-108. http://dx.doi. org/10.1108/13217341111130579

Du Toit, E., Erasmus, P., Kotze, L., Ngwenya, S., Thomas, K. \& Viviers, S., 2010, Corporate finance: A South African perspective, Cape Town, Oxford University Press Southern Africa.

Ernst \& Young, 2012, Six Growing Trends in Corporate Sustainability, Available online: www.ey.com

Esty, D.C., \& Winston, A.S., 2009. Green to Gold, How Smart companies use environmental strategy to innovate, create value and build competitive advantage. Hoboken, New Jersey: Wiley.

Global Reporting Initiative (GRI), 2011, Sustainability Reporting Guidelines, viewed n.d., from, http://www.globalreporting.org 
Global Reporting Initiative (GRI), 2013, Sustainability Reporting Guidelines, viewed n.d., from http://www.globalreporting.org

Hair, J. F. Jr; Anderson, R. E., Tatham, R. L. \& Black, William C., 1998., Multivariate Data Analysis, 5th ed., viewed n.d., from http://www.education.umd.edu/EDMS/fac/ Hancock/Course_Materials/EDMS771/readings/CanonicalCorrelationChapter.pdf

Hahn, T., Preuss, L., Pinkse, J. \& Figge, F., 2015, 'Cognitive frames in corporate sustainability: managerial sense making with paradoxical and business case frames', Academy of Management 4015, 18-42.

Hodgson, P. \& Burke, P., 2011, Multiple messages: Sustainability reporting in transparent times, viewed n.d., from http://www.sabmiller.com

Magness, V., 2010, 'Environmental disclosure in the mining industry: a signalling paradox?' In M. Freedman, \& B. Jaggi (Eds.), Sustainability, Environmental Performance and Disclosures Advances in Environmental Accounting \& Management, vol. 4, pp. 55-81.

Montabon, F., Scroufe, R. \& Narashiman, R., 2007, 'An examination of corporate reporting, environmental management practices and firm performance', Journal of Operations Management 25(5), 998-1014. http://dx.doi.org/10.1016/j. jom.2006.10.003

Pinter, L., Hardi, P. \& Bartelmus, P 2005, 'Indicators of sustainable development: Proposals for a way forward', Discussion paper prepared under a Consulting Agreement on behalf of the UN Division for Sustainable Development, viewed n.d., from http://www.iisd.org

Porter, M.E. \& van der Linde, C., 1995, 'Green and competitive: Ending the stalemate', Harvard Business Review 73(5), 120-134.

PriceWaterhouseCoopers, 2009, Executive guide to King III, viewed n.d., from http:// www.pwc.co.za

Reed, D.J., 2001, Stalking the elusive business case for corporate sustainability, World Resources Institute, Washington, DC.
Salzmann, O., Ionescu-Somers, A. \& Steger, U., 2005, 'The business case for corporate sustainability: Literature review and research options', European Management Journal 23(1), 27-36. http://dx.doi.org/10.1016/j.emj.2004. 12.007

Sarfaty, G., 2013, 'Regulating through numbers: A case study of corporate sustainability reporting', Virginia Journal of International Law, viewed n.d., from http://www. managementexchange.com/hack/fixing-corporate-sustainability-reportingstandards

Schaltegger, S. \& Burritt, R.L., 2010, 'Sustainability accounting for companies: Catchphrase or decision support for business leaders?' Journal of World Business 45, 375-384. http://dx.doi.org/10.1016/j.jwb.2009.08.002

Searcy, C. \& Elkhawas, D., 2012, 'Corporate sustainability ratings: an investigation into how corporations use the Dow Jones Sustainability Index', Journal of Cleaner Production 35, 79-92. http://dx.doi.org/10.1016/j.jclepro.2012.05.022

Sonnenberg, D. \& Hamman, R., 2006, 'The JSE Socially Responsible Investment Index and the state of sustainability reporting in South Africa', Development Southern Africa 23 (2). http://dx.doi.org/10.1080/03768350600707942

Sustainability report, 2011, A brief history of sustainability, viewed n.d., from http:// www.sustreport.org

Sutton, P. 2004 'What is Sustainability? Written for Eingana', The Journal of the Victorian Association for Environmental Education, viewed n.d., from http://www. green-innovations.asn.au

Walker, D. \& Meiring, I., 2010, King code and developments in corporate governance, vi Legal Brief, viewed September 2012, from http://uscdn.creamermedia. co.za/assets/articles/attachments/29922_king_code_and_corporate governance092010.pdf

World Business Council for Sustainable Development (WBCSD), 2002, The business case for sustainable development, viewed n.d., from http://www.wbcsd.org/ work-program/sector-projects/cement/local-impacts.aspx 


\section{Appendix 1: Rating sheet}

Sustainability performance of listed companies

Company:

\begin{tabular}{|c|c|c|c|c|c|c|c|c|}
\hline \multirow[t]{2}{*}{ Question } & \multirow[t]{2}{*}{ Attribute } & \multirow[t]{2}{*}{ Yes / No } & \multicolumn{5}{|c|}{ Intensity Scale } & \multirow[t]{2}{*}{ Notes, Pg Numbers } \\
\hline & & & \multicolumn{3}{|c|}{ Low } & \multicolumn{2}{|c|}{ High } & \\
\hline \multicolumn{9}{|c|}{ Operational practices } \\
\hline 1 & Recycling & & 1 & 2 & 3 & 4 & 5 & \\
\hline 2 & Waste reduction (Proactive) & & 1 & 2 & 3 & 4 & 5 & \\
\hline 3 & Waste reduction (Reactive) & & 1 & 2 & 3 & 4 & 5 & \\
\hline 4 & Remanufacturing & & 1 & 2 & 3 & 4 & 5 & \\
\hline 5 & Substitution & & 1 & 2 & 3 & 4 & 5 & \\
\hline 6 & Consume internally & & 1 & 2 & 3 & 4 & 5 & \\
\hline 7 & Packaging & & 1 & 2 & 3 & 4 & 5 & \\
\hline 8 & Spreading risk & & 1 & 2 & 3 & 4 & 5 & \\
\hline 9 & Market for waste & & 1 & 2 & 3 & 4 & 5 & \\
\hline 10 & Energy & & 1 & 2 & 3 & 4 & 5 & \\
\hline 11 & Money spent on environment & & 1 & 2 & 3 & 4 & 5 & \\
\hline 12 & Environmental information & & 1 & 2 & 3 & 4 & 5 & \\
\hline \multicolumn{9}{|l|}{ Tactical } \\
\hline 14 & $\mathrm{SCM}$ & & 1 & 2 & 3 & 4 & 5 & \\
\hline 15 & Early supplier involvement & & 1 & 2 & 3 & 4 & 5 & \\
\hline 16 & Environmental standard for suppliers & & 1 & 2 & 3 & 4 & 5 & \\
\hline 17 & Environmental audits suppliers & & 1 & 2 & 3 & 4 & 5 & \\
\hline 18 & Environmental awards & & 1 & 2 & 3 & 4 & 5 & \\
\hline 19 & Environmental participation & & 1 & 2 & 3 & 4 & 5 & \\
\hline 20 & Life cycle analysis & & 1 & 2 & 3 & 4 & 5 & \\
\hline 21 & Product development / innovations & & 1 & 2 & 3 & 4 & 5 & \\
\hline 22 & Design & & 1 & 2 & 3 & 4 & 5 & \\
\hline 23 & Design targets / goals & & 1 & 2 & 3 & 4 & 5 & \\
\hline 24 & Environmental risk analysis & & 1 & 2 & 3 & 4 & 5 & \\
\hline 25 & Environmental management systems & & 1 & 2 & 3 & 4 & 5 & \\
\hline 26 & Communication & & 1 & 2 & 3 & 4 & 5 & \\
\hline 28 & Corporate policies and procedures & & 1 & 2 & 3 & 4 & 5 & \\
\hline 29 & Environmental mission statement & & 1 & 2 & 3 & 4 & 5 & \\
\hline 30 & Employee programmes & & 1 & 2 & 3 & 4 & 5 & \\
\hline 31 & Environmental department & & 1 & 2 & 3 & 4 & 5 & \\
\hline 32 & Surveillance of market & & 1 & 2 & 3 & 4 & 5 & \\
\hline 33 & Strategic alliance & & 1 & 2 & 3 & 4 & 5 & \\
\hline \multicolumn{9}{|c|}{ Social upliftment initiatives } \\
\hline 34 & Enterprise development & & 1 & 2 & 3 & 4 & 5 & \\
\hline 35 & Transformation & & 1 & 2 & 3 & 4 & 5 & \\
\hline 36 & Skills development & & 1 & 2 & 3 & 4 & 5 & \\
\hline 37 & Health and safety / HIV & & 1 & 2 & 3 & 4 & 5 & \\
\hline 38 & Corporate social investment & & 1 & 2 & 3 & 4 & 5 & \\
\hline \multicolumn{9}{|c|}{ Environmental / financial / market performance } \\
\hline 41 & Reduction in incidents & & 1 & 2 & 3 & 4 & 5 & \\
\hline 42 & Environmental certification & & 1 & 2 & 3 & 4 & 5 & \\
\hline 43 & Continuous improvement & & 1 & 2 & 3 & 4 & 5 & \\
\hline 44 & Recycling performance & & 1 & 2 & 3 & 4 & 5 & \\
\hline 45 & Customer perception & & 1 & 2 & 3 & 4 & 5 & \\
\hline 46 & Independent audits & & 1 & 2 & 3 & 4 & 5 & \\
\hline 47 & Waste reduction & & 1 & 2 & 3 & 4 & 5 & \\
\hline 48 & Resource consumption & & 1 & 2 & 3 & 4 & 5 & \\
\hline 49 & Cost savings & & 1 & 2 & 3 & 4 & 5 & \\
\hline 50 & Return on assets & & 1 & 2 & 3 & 4 & 5 & \\
\hline 51 & Return on investment & & 1 & 2 & 3 & 4 & 5 & \\
\hline 52 & Operating earnings & & 1 & 2 & 3 & 4 & 5 & \\
\hline
\end{tabular}


Appendix 1 (Continues...).

\begin{tabular}{|c|c|c|c|c|c|c|c|c|}
\hline \multirow[t]{2}{*}{ Question } & \multirow[t]{2}{*}{ Attribute } & \multirow[t]{2}{*}{ Yes / No } & \multicolumn{5}{|c|}{ Intensity Scale } & \multirow[t]{2}{*}{ Notes, Pg Numbers } \\
\hline & & & & Low & & & & \\
\hline & Sales growth & & 1 & 2 & 3 & 4 & 5 & \\
\hline & Innovation product & & 1 & 2 & 3 & 4 & 5 & \\
\hline & Innovation process & & 2 & 3 & 4 & 5 & 6 & \\
\hline
\end{tabular}

